\title{
Predators associated with the pine bark adelgid (Hemiptera: Adelgidae), a native insect in Appalachian forests, United States of America, in its southern range
}

\author{
Holly A. Wantuch, ${ }^{1}$ Nathan P. Havill, E. Richard Hoebeke, Thomas P. Kuhar, \\ Scott M. Salom
}

\begin{abstract}
The pine bark adelgid, Pineus strobi (Hartig) (Hemiptera: Adelgidae), is an herbivore native to eastern North America that specialises on eastern white pine, Pinus strobus Linnaeus (Pinaceae). Little is known about $P$. strobi, especially in its southern range in the Appalachian Mountains, United States of America, and the composition of its predator complex has not yet been documented in this region. The current study identifies arthropod predators associated with P. strobi in Appalachian forests of Virginia based on a two-year survey. Predators were identified using morphology and DNA barcoding. Predator species include: Laricobius rubidus LeConte (Coleoptera: Derodontidae), Leucopis piniperda Malloch (Diptera: Chamaemyiidae), and Leucopis argenticollis Zetterstedt (Diptera: Chamaemyiidae), that are known adelgid specialists. Also found were predators from the families Cecidomyiidae (Diptera), Coccinellidae (Coleoptera), Chrysopidae (Neuroptera), Hemerobiidae (Neuroptera), and Syrphidae (Diptera). The Cecidomyiidae were especially diverse, with 14 different species inferred from their DNA barcodes. Knowledge of this predator complex is particularly valuable for anticipation and detection of potential interactions between native predator species and those that are being considered for the introduction for biological control of invasive adelgid pests within the southern Appalachian ecosystem.
\end{abstract}

\section{Introduction}

The pine bark adelgid, Pineus strobi (Hartig) (Hemiptera: Adelgidae), is an herbivore that feeds primarily on eastern white pine, Pinus strobus Linnaeus (Pinaceae) (Doane 1961). Although it is an occasional aesthetic pest on Christmas trees and ornamentals, feeding by $P$. strobi does not appear to affect $P$. strobus health, even when adelgid densities are high (Clark and Brown 1960). Thus, little, if any, $P$. strobi management is necessary. The species has been reported in the Pacific Northwest of North America on Pinus monticola (Douglas ex Don), and its pest status there is undetermined (Darr et al. 2018). It is also an occasional nursery pest in the United Kingdom (Matosevic and Zivkovic 2013).
While $P$. strobi is not considered a significant pest, it shares its geographic range with nonnative adelgids that inflict substantial ecologic and economic damage. One invasive species is the hemlock woolly adelgid, Adelges tsugae (Annand) (Hemiptera: Adelgidae), an ecologically and economically destructive invasive species introduced to the eastern United States of America from Japan that feeds on hemlock (Tsuga Endlicher (Carrière); Pinaceae) species (Havill et al. 2016). Another, the balsam woolly adelgid, Adelges piceae (Ratzeburg) (Hemiptera: Adelgidae), from Europe and Central Asia is invasive across the United States of America and Canada and causes high mortality in native North American fir (Abies Miller; Pinaceae) species (Jenkins 2003; McManamay et al. 2011). In

Received 28 April 2018. Accepted 17 July 2018. First published online 15 November 2018.

H.A. Wantuch, ${ }^{1}$ T.P. Kuhar, S.M. Salom, Virginia Tech, 216 Price Hall, Blacksburg, Virginia, 24060, United States of America

N.P. Havill, 51 Mill Pond Road, Hamden, Connecticut, 06514, United States of America

E.R. Hoebeke, Georgia Museum of Natural History, University of Georgia, 101 Cedar Street, Athens, Georgia, 30602, United States of America

${ }^{1}$ Corresponding author (e-mail: wholly3@vt.edu)

Subject editor: Jon Sweeney

doi: $10.4039 /$ tce. 2018.53 
addition, the pine adelgid, Pineus boerneri Annand (Hemiptera: Adelgidae), was introduced to New England, United States of America where it is reported to damage red pine, Pinus resinosa Aiton (McClure 1982; Centre for Agriculture and Bioscience International 2017). The origin of P. boerneri is not clear, but it may be native to East Asia (McClure 1984). Biological control is an important option for controlling invasive adelgids on a landscape scale (Mausel and Salom 2014; Montgomery and Havill 2014). It is reasonable to consider that predators of $P$. strobi may also use these alien species because they are related to $P$. strobi and share habitats.

In the northern reaches of the native range of $P$. strobi, a number of naturally occurring predators have been identified from the families Coccinellidae (Coleoptera), Chamaemyiidae (Diptera), Cecidomyiidae, and Hemerobiidae (Neuroptera), as well as Laricobius rubidus LeConte (Coleoptera: Derodontidae) (Wilson 1938; Raske and Hodson 1964; Sluss and Foote 1973; Montgomery and Lyon 1995a). Laricobius rubidus is considered a specialist predator of $P$. strobi and is not reported on other prey native to eastern North America (Brown 1944; Clark and Brown 1960; Lawrence and Hlavac 1979; Montgomery and Lyon 1995a). Previous studies of L. rubidus phenology report that adults are present from March to June and eggs are laid within P. strobi ovisacs during April and May (Clark and Brown 1960; Zilahi-Balogh et al. 2005). There are four instars, each of which, like the adult, feeds on all $P$. strobi life stages. The last instar is believed to drop to the soil for pupation (Clark and Brown 1960). This phenology is highly synchronised with that of $P$. strobi. In the Appalachain Mountains of southwestern Virginia, United States of America, P. strobi reproduction begins in early April with a large spike in egg production following a quiescent period during the winter (Wantuch et al. 2017).

Following the introduction of the hemlock woolly adelgid, it became apparent that $L$. rubidus could also feed and complete development on this invasive prey species (Montgomery and Lyon 1995b; Zilahi-Balogh et al. 2005; Mausel et al. 2008; Story et al. 2012). Adelges tsugae has a similar life cycle to $P$. strobi in that the majority of individuals are wingless and immobile following the first instar and reproduce asexually (Raske and
Hodson 1964; McClure 1989; Havill and Foottit 2007). However, there are differences in that $P$. strobi is not active in the winter (Raske and Hodson 1964; Wantuch et al. 2017); whereas, A. tsugae has two distinct generations per year with nymphs developing to adults by late winter and laying eggs in late winter to early spring, and adult $A$. tsugae aestivate over much of the summer (McClure 1989; Lamb et al. 2007; Mausel et al. 2008). In contrast, $P$. strobi does not diapause and has multiple overlapping generations resulting in all life stages being apparently available to predators from March to November in southwestern Virginia (Wantuch et al. 2017). Because forest stands of $P$. strobus are often intermixed with eastern hemlocks, Tsuga canadensis (Linnaeus) and Carolina hemlock, Tsuga caroliniana Engelman (Burns and Honkala 1990), L. rubidus has ample opportunity for interaction with A. tsugae. Laricobius nigrinus Fender (Coleoptera: Derodontidae), a close relative of L. rubidus from the Pacific Northwest has been released in the eastern United States of America as a biological control agent of A. tsugae (Mausel et al. 2010; Davis et al. 2011). These two Laricobius Rosenhauer species are known to produce fertile hybrids in the field, and both species and their hybrids are all known to feed on A. tsugae and P. strobi (Havill et al. 2012; Fischer et al. 2015).

Little is known regarding predators of $P$. strobi, particularly in the southern portion of its range. Host switching of Laricobius species, and possibly other predators, between native and nonnative adelgids warrants investigation of the incidence and phenology of $P$. strobi predators in its previously unstudied southern range. The predator complex of $P$. strobi may exert pressure on these exotic adelgid species, and newly introduced biological controls could impact the native community of predators on $P$. strobi. The current study documents the predator complex associated with P. strobi in the forests of the Appalachain Mountain Range in southwestern Virginia, with specific attention to the phenology of L. rubidus.

\section{Materials and methods}

Specimens were collected from three sites in southwestern Virginia: Peak Creek, at Gatewood Park and Reservoir, Pulaski, $37.06217^{\circ} \mathrm{N}$, 
$80.83633^{\circ} \mathrm{W}$; Hussy Mountain, in Mount Rogers National Recreation Area, Speedwell, $36.77223^{\circ} \mathrm{N}$, $81.17521^{\circ} \mathrm{W}$; and Dismal Falls, in George Washington and Jefferson National Forest, Giles County, $37.19263^{\circ} \mathrm{N}, 80.89230^{\circ} \mathrm{W}$. Sampling occurred approximately every two weeks from 13 September 2013 to 28 April 2016. This coincided with a study of $P$. strobi phenology at these same sites (Wantuch et al. 2017). Samples were taken from eastern white pine trees colonised by $P$. strobi and were limited to parts of trees accessible from the ground with hand pruners. Mature trees, saplings, and seedlings were sampled opportunistically wherever $P$. strobi was present. Because of the patchy distribution of this insect, it was not possible to implement a structured sampling scheme with regard to tree age class. At each site, on each sampling date, a minimum of 50 trees infested with $P$. strobi were sampled using a beating sheet. Because $P$. strobi populations were scarce in these forest environments, it was not possible to ensure that infested trees that had been beating-sheet sampled were not sampled on future visits via beat sheeting or branch tip excision. In addition, excised infested branch tips of various lengths and bark samples were collected during each visit and examined under a dissecting microscope in the laboratory and predators were removed. Infested tree samples were not restricted to any certain size, but instead were chosen so as to maximise the number of adelgids collected on each. The number of tree samples collected varied based upon adelgid density, with the goal being to collect a minimum of 100 nonegg $P$. strobi from each site on each date. Beat sheet samples consisted of adult insects, with the exception of coccinellid larvae, and all other immature predators were collected from branch tips using a dissecting microscope. All predator specimens were stored in a freezer at $-20{ }^{\circ} \mathrm{C}$, and immature insects were placed in $95 \%$ ethanol.

Adult insects were identified using morphological characters; voucher specimens are deposited in the Virginia Tech Insect Museum, Blacksburg, Virginia, United States of America and in the University of Georgia Collection of Arthropods, Athens, Georgia, United States of America. All larval specimens were identified using DNA barcoding, with the exception of $L$. rubidus. Laricobius larvae can be identified to genus using morphology, but cannot be distinguished to species morphologically, and so it is possible to confuse L. rubidus and L. nigrinus. The collection sites were located in a region that should only have $L$. rubidus because the closest release site for L. nigrinus to any collection site was $19 \mathrm{~km}$ away. Nevertheless, a subset of larvae were identified with DNA barcodes (Davis et al. 2011) to ensure that the non-native L. nigrinus or their hybrids were not present in the populations. All other predator larvae were identified by comparing DNA barcodes to records in the Barcode of Life Database (BOLD) (Ratnasingham and Hebert 2007). For all specimens, DNA was extracted using the Mag-Bind Blood and Tissue Kit (Omega Bio-Tek, Norcross, Georgia, United States of America). The cuticles were preserved after proteinase digestion and slide mounted as vouchers, which were deposited at the Yale Peabody Museum of Natural History (New Haven, Connecticut, United States of America). The 5' end of mitochondrial cytochrome c oxidase subunit I (COI) was amplified using primers LepF1 and LepR1 (Hebert et al. 2004), and sequencing was performed at the DNA Analysis Facility on Science Hill, Yale University using an ABI 3730 sequencer (Life Technologies, Grand Island, New York, United States of America). Chromatograms were edited using Geneious v7 (www.geneious. com; Kearse et al. 2012). Samples were identified to the most specific taxon possible by searching the Barcode of Life Database (www.barcodinglife. org). All DNA sequences generated for this study were deposited in GenBank with accession numbers MH119461-MH119573.

\section{Results}

\section{Coleoptera: Derodontidae}

A total of 156 adults, 44 larvae, and 17 eggs of Laricobius rubidus were collected at all three sites over the course of the study (Table 1). Adult L. rubidus were consistently active beginning in the fall during October 2013 and early December of 2014 and 2015 (Fig. 1). Across all years there was a period of inactivity during the coldest parts of the winter during which no adults were collected. In 2013, this occurred from December to late February. In 2014, no beetles were observed from January to mid-February, and in 2015, adults were not collected from January to April. 
In addition, two eggs were found in late March 2013, one egg was found in March 2015, 11 eggs and 9 larvae recovered from branch tips in April 2015, three eggs were found in March 2016, and 33 larvae were collected from branch tips in April 2016. Laricobius rubidus activity ceased no later than May and appeared to have only one generation per year.

\section{Coleoptera: Coccinellidae}

Adult Coccinellidae were collected October 2013, May-October 2014, and April to late September 2015. Larvae were observed from May to July of 2014 and 2015 (Table 1; Fig. 3). The most frequently collected species identified was Harmonia axyridis (Pallas). Five species of the genus Scymnus Kugelann were also collected on eastern white pines infested with $P$. strobi: $S$. indianensis Weise, S. festatus Wingo, S. americanus Mulsant, $S$. creperus Mulsant, and $S$. fraternus LeConte. Other adult coccinellid species found in association with $P$. strobi were Brachiacantha ursina (Fabricius) and Diomus terminatus (Say).

\section{Diptera: Chamaemyiidae}

Leucopis argenticollis Zetterstedt larvae were collected from branch tips from April to August and L. piniperda Malloch from June to July. Five empty Leucopis Meigen puparia were collected from mid-February through late March and in September of 2014, but it was not possible to identify these two species. One puparium was collected in December 2015 from which an adult L. argenticollis emerged (Table 1; Fig. 2).

\section{Diptera: Cecidomyiidae}

Cecidomyiid larvae were found on branch tips from April to October (Table 1; Fig. 4). Fourteen putative species were identified using DNA barcoding, however none matched records identified to species in the Barcode of Life Database. Specimens from eight of these putative species (species $2,4,5,6,11,13$, and 14) were collected from within $P$. strobi ovisacs, suggesting that they are likely predaceous. An individual of species 5 was observed eating an adult adelgid and its eggs. Specimens of the other putative species were collected on or near the adelgids.

\section{Diptera: Syrphidae}

Four species of syrphid larvae were collected: Allograpta obliqua (Say) in May 2015, Syrphus torvus Osten Sacken in April 2016, Toxomerus geminatus (Say) in June 2014 and October 2015, and Eupeodes Osten Sacken species in September 2013 (Table 1).

\section{Neuroptera: Hemerobiidae}

Hemerobiid larvae were observed in the field during late April and May of 2014 and 2015, and an adult was observed in December 2013 (Table 1). Larval DNA barcoding was inconclusive because DNA sequences recovered from these samples matched to those of Sciaridae (Diptera) and Chironomidae (Diptera) in the Barcode of Life Database, suggesting that sequences originated either from larval gut contents or from remnants of carcasses that they are known to carry as camouflage.

\section{Neuroptera: Chrysopidae}

Three specimens of Glenochrysa lineaticornis (Fitch) were collected on 18 September 2015 (Table 1).

\section{Discussion}

The phenology of L. rubidus observed in this study differs markedly from previous observations in the northern range of the beetle, where adults were found from March to June and eggs were laid in April and May (Clark and Brown 1960; Zilahi-Balogh et al. 2005). In the present study, L. rubidus was present as early as midOctober through the beginning of May, and absent from late December to mid-February. Eggs were found March to April, and larvae were collected in April (Fig. 1). These data suggest an approximately one month shift in activity between southern and northern ranges of L. rubidus from late winter through summer with regard to adult, egg, and larval presence, which may be explained by warmer southern temperatures. The absence of adults from December to mid-February may be due to $L$. rubidus retreating into the soil in order to avoid cold winter temperatures.

Laricobius rubidus and L. nigrinus are very closely related species (Montgomery et al. 2011), but they have different prey preferences. 
Table 1. Predatory species associated with Pineus strobi on Pinus strobus in southwestern Virginia collected 2013-2016 with the number of each life stage collected (eggs, larvae, pupae, adults).

\begin{tabular}{|c|c|c|c|}
\hline Order & Family & Genus & Species \\
\hline \multirow[t]{9}{*}{$\begin{array}{l}\text { Coleoptera } \\
\qquad(1,61,0,241)\end{array}$} & $\begin{array}{l}\text { Derodontidae } \\
\quad(17,44,0,156)\end{array}$ & $\begin{array}{l}\text { Laricobius } \\
\qquad(17,44,0,156)\end{array}$ & L. rubidus $(17,44,0,156)$ \\
\hline & \multirow{8}{*}{$\begin{array}{l}\text { Coccinellidae } \\
\quad(0,17,0,85)\end{array}$} & Harmonia $(0,0,0,65)$ & H. axyridis $(0,0,0,65)$ \\
\hline & & Scymnus $(0,0,0,15)$ & S. americanus $(0,0,0,3)$ \\
\hline & & & S. creperus $(0,0,0,1)$ \\
\hline & & & S. festatus $(0,0,0,1)$ \\
\hline & & & S. fraternus $(0,0,0,8)$ \\
\hline & & & S. indianensis $(0,0,0,1)$ \\
\hline & & $\begin{array}{c}\text { Brachiacantha } \\
\quad(0,0,0,1)\end{array}$ & B. ursina $(0,0,0,1)$ \\
\hline & & Diomus $(0,0,0,1)$ & D. terminatus $(0,0,0,1)$ \\
\hline \multirow[t]{20}{*}{ Diptera $(2,107,7,0)$} & \multirow[t]{2}{*}{$\begin{array}{l}\text { Chamaemyiidae } \\
(1,24,7,0)\end{array}$} & \multirow[t]{2}{*}{ Leucopis $(1,22,1,0)$} & $\begin{array}{l}\text { L. argenticollis (BOLD:ACH4033, 100\%) } \\
(1,20,1,0)\end{array}$ \\
\hline & & & $\begin{array}{l}\text { L. piniperda (BOLD:ACC5514 100\%) } \\
(0,2,0,0)\end{array}$ \\
\hline & \multirow[t]{14}{*}{$\begin{array}{l}\text { Cecidomyiidae } \\
\quad(0,74,0,0)\end{array}$} & \multirow[t]{14}{*}{-} & $\begin{array}{l}\text { Species } 1 \text { (BOLD:ABX3666, } \\
98 \%)(0,1,0,0)\end{array}$ \\
\hline & & & $\begin{array}{l}\text { Species } 2 \text { (BOLD:AAQ0655, 100\%) } \\
\quad(0,33,0,0)\end{array}$ \\
\hline & & & $\begin{array}{l}\text { Species } 3 \text { (BOLD:ACK9896, 92.2\%) } \\
\quad(0,1,0,0)\end{array}$ \\
\hline & & & $\begin{array}{l}\text { Species } 4 \text { (BOLD:AAH3755, 100\%) } \\
\quad(0,11,0,0)\end{array}$ \\
\hline & & & $\begin{array}{l}\text { Species } 5 \text { (BOLD:AAY6419, 100\%) } \\
\quad(0,2,0,0)\end{array}$ \\
\hline & & & $\begin{array}{l}\text { Species } 6 \text { (BOLD:ACK3142, 100\%) } \\
\quad(0,6,0,0)\end{array}$ \\
\hline & & & $\begin{array}{l}\text { Species } 7 \text { (BOLD:AAY6411, 97.5\%) } \\
\quad(0,2,0,0)\end{array}$ \\
\hline & & & $\begin{array}{l}\text { Species } 8 \text { (BOLD:ACL3715, 94.2\%) } \\
(0,1,0,0)\end{array}$ \\
\hline & & & $\begin{array}{l}\text { Species } 9 \text { (BOLD:AAV5558, 94.6\%) } \\
\quad(0,2,0,0)\end{array}$ \\
\hline & & & $\begin{array}{l}\text { Species } 10 \text { (BOLD:ABW7837, 99.4\%) } \\
\quad(0,3,0,0)\end{array}$ \\
\hline & & & $\begin{array}{l}\text { Species } 11 \text { (BOLD:AAH3720, 100\%) } \\
\quad(0,3,0,0)\end{array}$ \\
\hline & & & $\begin{array}{l}\text { Species } 12 \text { (BOLD:AAM6059, 99.8\%) } \\
\quad(0,1,0,0)\end{array}$ \\
\hline & & & $\begin{array}{l}\text { Species } 13 \text { (BOLD:AAH3734, 100\%) } \\
\quad(0,1,0,0)\end{array}$ \\
\hline & & & $\begin{array}{l}\text { Species } 14 \text { (BOLD:ACC8281, 92.1\%) } \\
(0,1,0,0)\end{array}$ \\
\hline & \multirow[t]{4}{*}{ Syrphidae $(0,6,0,0)$} & Toxomerus $(0,2,0,0)$ & $\begin{array}{l}\text { T. geminatus (BOLD:AAC1312, 100\%) } \\
(0,2,0,0)\end{array}$ \\
\hline & & Syrphyus $(0,1,0,0)$ & S. torvus (BOLD:AAC6088, 100\%) $(0,1,0,0)$ \\
\hline & & Allograpta $(0,2,0,0)$ & $\begin{array}{l}\text { A. obliqua (BOLD:AAD8276, 100\%) } \\
(0,2,0,0)\end{array}$ \\
\hline & & Eupeodes $(0,1,0,0)$ & $\begin{array}{l}\text { Species } 1 \text { (BOLD:AAB2384, 99.9\%) } \\
\quad(0,1,0,0)\end{array}$ \\
\hline
\end{tabular}


Table 1. Continued

\begin{tabular}{llll}
\hline Order & Family & Genus & Species \\
\hline $\begin{array}{c}\text { Neuroptera } \\
(0,18,0,1)\end{array}$ & Hemerobiidae $(0,3,0,1)-$ & - \\
& Chrysopidae $(0,3,0,0)$ & $\begin{array}{c}\text { Glenochrysa } \\
(0,3,0,0)\end{array}$ & $\begin{array}{c}\text { G. lineaticornis (BOLD:AAH7094 98.6\%) } \\
(0,3,0,0)\end{array}$ \\
\hline
\end{tabular}

Notes: Specimens were identified to various levels; counts of broader levels include those of narrower levels within them. Cecidomyiid specimens could not be identified to species. Those that could be grouped together based on their closest match to a DNA Barcode of Life Database (BOLD) barcode index numbers (BINs) are given arbitrary species numbers. Their BINs are shown in parentheses, and the percent sequence match follows each BIN.

Fig. 1. Number of Laricobius rubidus of each life stage collected on each sampling date (2013-2016) in southwest Virginia.

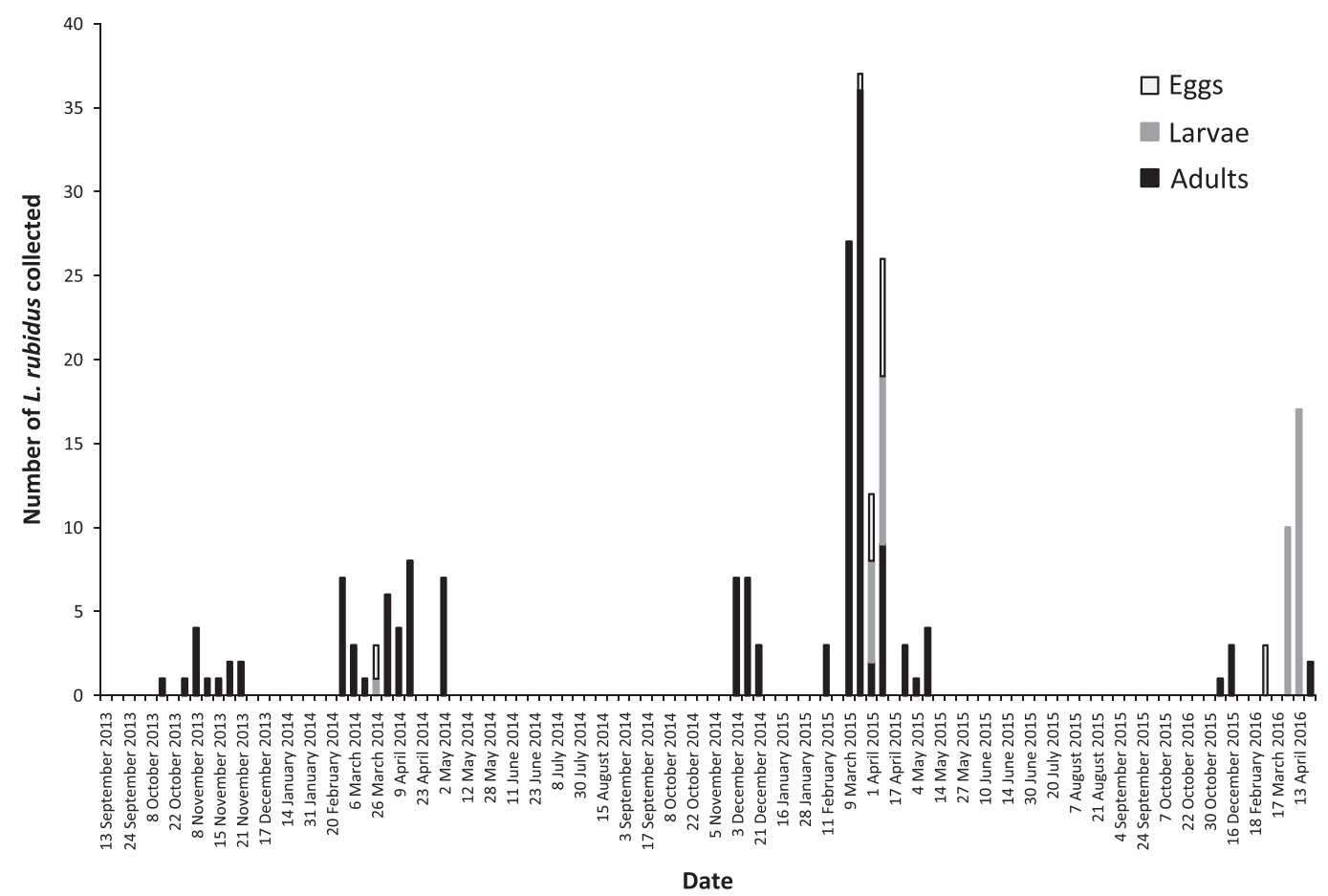

Laricobius rubidus prefers pine adelgids while L. nigrinus prefers hemlock adelgids (ZilahiBalogh et al. 2002, 2005; Arsenault et al. 2015). Laricobius rubidus can be found feeding on A. tsugae in the field but in lower numbers than on P. strobi (Montgomery and Lyon 1995b; ZilahiBalogh et al. 2005; Mausel et al. 2008; Havill et al. 2012; Story et al. 2012; Fischer et al. 2015). Conversely, L. nigrinus can be found feeding on $P$. strobi in the field, but in lower numbers than on A. tsugae (Fischer et al. 2015). Despite the difference in host preference, these species share many phenological and behavioural traits (Mausel et al. 2008). Both Laricobius species are active in the spring and fall, but they are not found on adelgid prey during late Spring through mid-Fall (mid-May to late October for L. rubidus in Virginia). This would seem maladaptive for $L$. rubidus because all stages of $P$. strobi are available as prey during this time (Wantuch et al. 2017). However, two other species of Laricobius, L. osakensis Shiyake and Montgomery and L. erichsonii Rosen (Coleoptera: Derodontidae), a European predator of A. piceae, are also 
Fig. 2. Number of Coccinellidae predators associated with $P$. strobi collected during each month of the sampling period (2013-2016) in southwest Virginia. Multiple samples were taken monthly and specimen counts are pooled here according to month and year. Specimens not identified beyond family are shown as Coccinellidae (larvae) and Coccinellidae (adults), respectively.

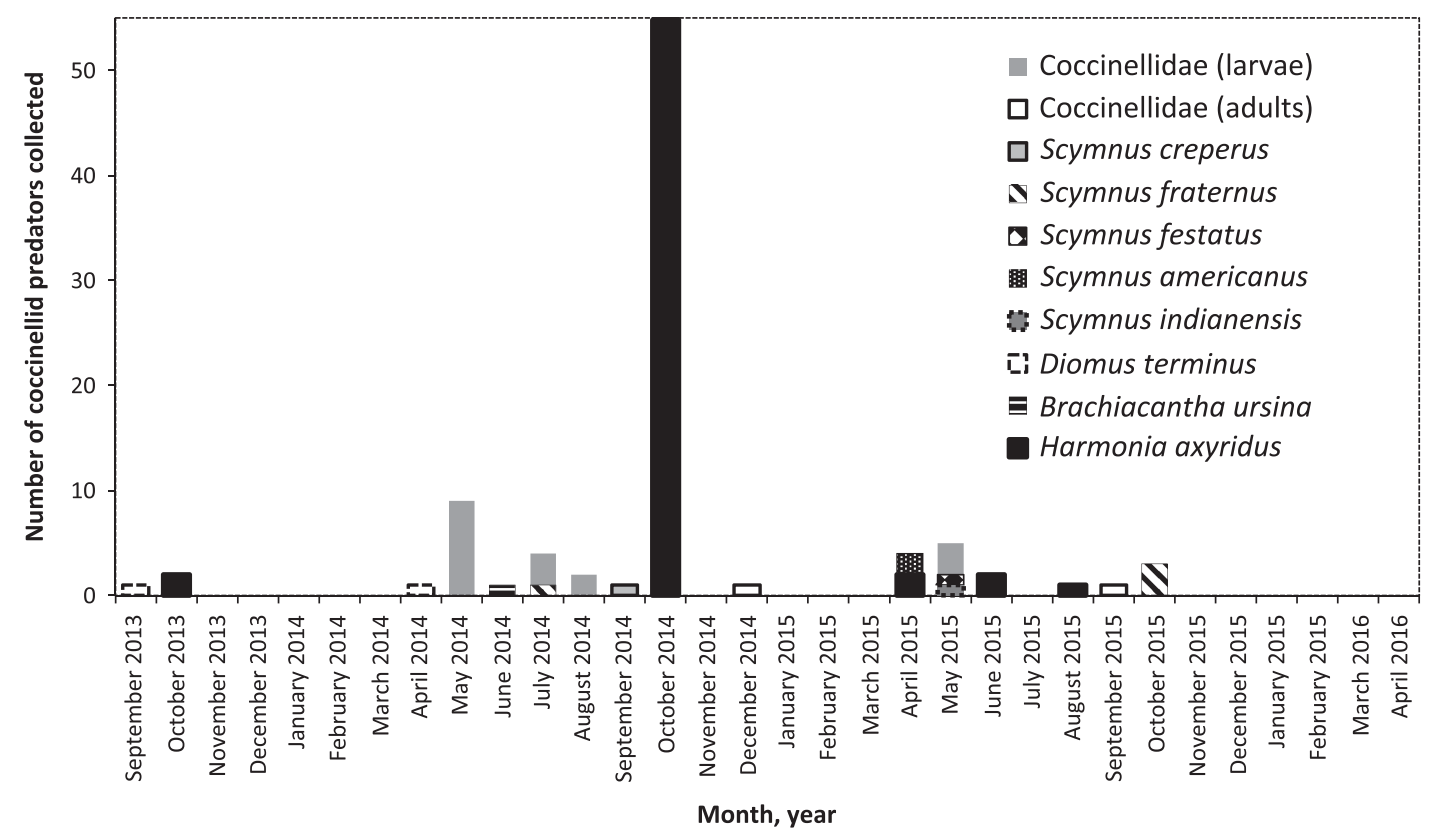

univoltine, with a period of aestivation while their prey are still available (Buffama 1962; ZilahiBalogh et al. 2003; Vieira et al. 2013). Since this trait is shared among all Laricobius species with known life cycle, it is likely that the existence of an obligate period of aestivation is fixed within the genus and not readily available for adaptation.

Two species of chamaemyiid flies were found on branch tip samples infested with $P$. strobi. The predaceous larval stage was observed from May to August in 2014 and in April 2016 (Fig. 2). Leucopis argenticollis was more abundant than L. piniperda. Both species are known to be predators of the native lineage of A. tsugae in western North America (Havill et al. 2018). These Leucopis species have not been reported on A. tsugae in the eastern United States of America, and eastern and western lineages of both Leucopis species have distinct genotypes that appear to specialise on different adelgid species. The western strains are currently being evaluated and released as biological control agents for A. tsugae (Ross et al. 2010; Grubin et al. 2011; Kohler et al. 2016; Motley et al. 2017; Havill et al. 2018). The current study shows that both Leucopis species are present in southwestern Virginia prior to release of the western lineages, which may aid establishment and ease ecological concerns regarding the introduction of foreign organisms to a new ecosystem. Not represented in this survey of predators was Neoleucopis pinicola (Malloch) (Diptera: Chamaemyiidae), a species previously found feeding on P. strobi (Clark and Brown 1957).

A large number of cecidomyiid larvae were found on branch tips in association with $P$. strobi. They were collected beginning in early April of 2014 and 2015 through September 2014 and October 2015. They were also collected in September 2013 (Fig. 4). DNA barcoding results suggest that there are 14 distinct species represented, although none match records that have been identified to species. This is not surprising as much is unknown about this highly diverse group (Mamaev and Krivosheina 1965; Gagné 1989). In fact, Hebert et al. (2016) suggested that Cecidomyiidae is likely the most diverse insect family in all of Canada, after an extensive survey 
Fig. 3. Chamaemyiidae predators associated with $P$. strobi collected during each month of the sampling period (2013-2016) in southwest Virginia. Multiple samples were taken monthly and specimen counts are pooled here according to month and year. Specimens not identified beyond family are shown as Chamaemyiidae (puparia).

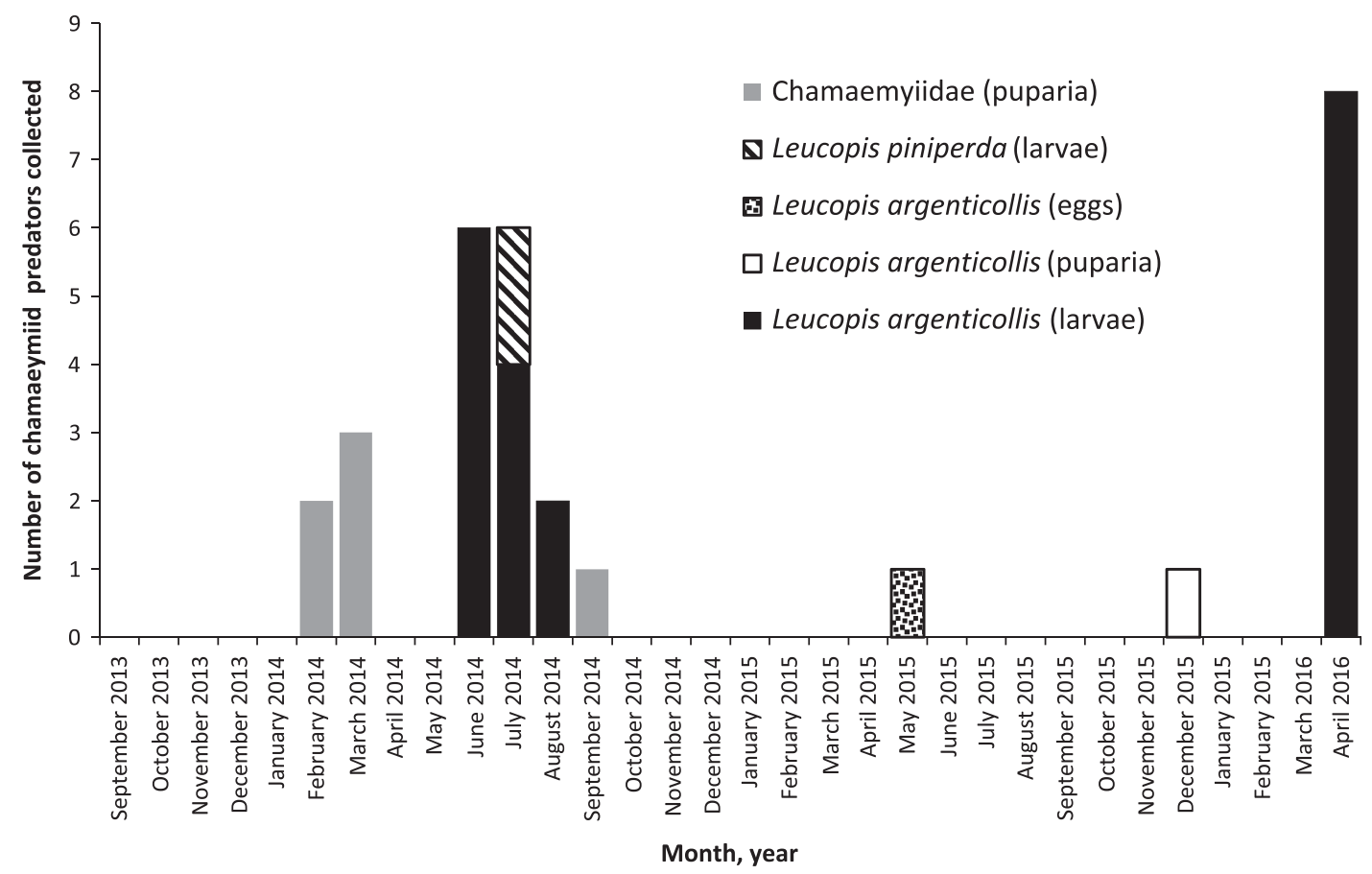

of over one million samples using DNA barcodes. Cecidomyiids have been documented as predators of other adelgid species as well. In the 1960s, a native predator of A. piceae, Aphidoletes thompsoni Mohn (Diptera: Cecidomyiidae), was released in North America as a biological control agent for $A$. piceae, though it was not effective (Humble 1994). Cecidomyiids were also a large proportion of predators collected by Wallace and Hain (2000) in western North Carolina in association with $A$. tsugae, though they were only found in June and July. Cecidomyiids have a broad range of life histories. Most are plant feeders and form galls, but some feed on fungi, sap, or are predators (Mamaev and Krivosheina 1965; Gagné 1989). Although it is possible some species collected in this study are not predaceous and were perhaps feeding on tree sap or fungi, one species was directly observed consuming $P$. strobi, and the presence of larvae from seven other species found within adelgid ovisacs is certainly suggestive of predatory behaviour. Species 2 and 4 with 33 and 11 specimens, respectively, were the most abundant and are therefore most likely to have the largest impact on $P$. strobi populations and could be investigated further.

The presence of several more generalist predators is consistent with other studies of adelgid predator communities (Montgomery and Lyon 1995a, 1995b; Wallace and Hain 2000). Adult and larval coccinellids were collected from April to October. The most frequently collected of these was Harmonia axyridis, an exotic beetle introduced to North America from eastern Asia as a biological control agent for aphid and scale pest management (Roy et al. 2016). The genus Scymnus includes predators of adelgids and aphids. Five members of this genus were found in association with $P$. strobi in this study: $S$. americanus, S. creperus, S. festatus, S. fraternus, and $S$. indianensis. Southwestern Virginia is within the known native ranges of all of these Scymnus species. A single Diomus terminatus specimen was found; this species is considered to be a generalist aphid feeder and is native to the eastern and Midwestern United States of America 
Fig. 4. Number of Cecidomyiidae predators associated with $P$. strobi collected each month during the sampling period (2013-2016) in southwest Virginia. Multiple samples were taken monthly and specimen counts are pooled here according to month and year. Specimens could not be identified by species but were grouped by barcode index number (BIN) and given arbitrary species designations. BOLD, Barcode of Life Database.

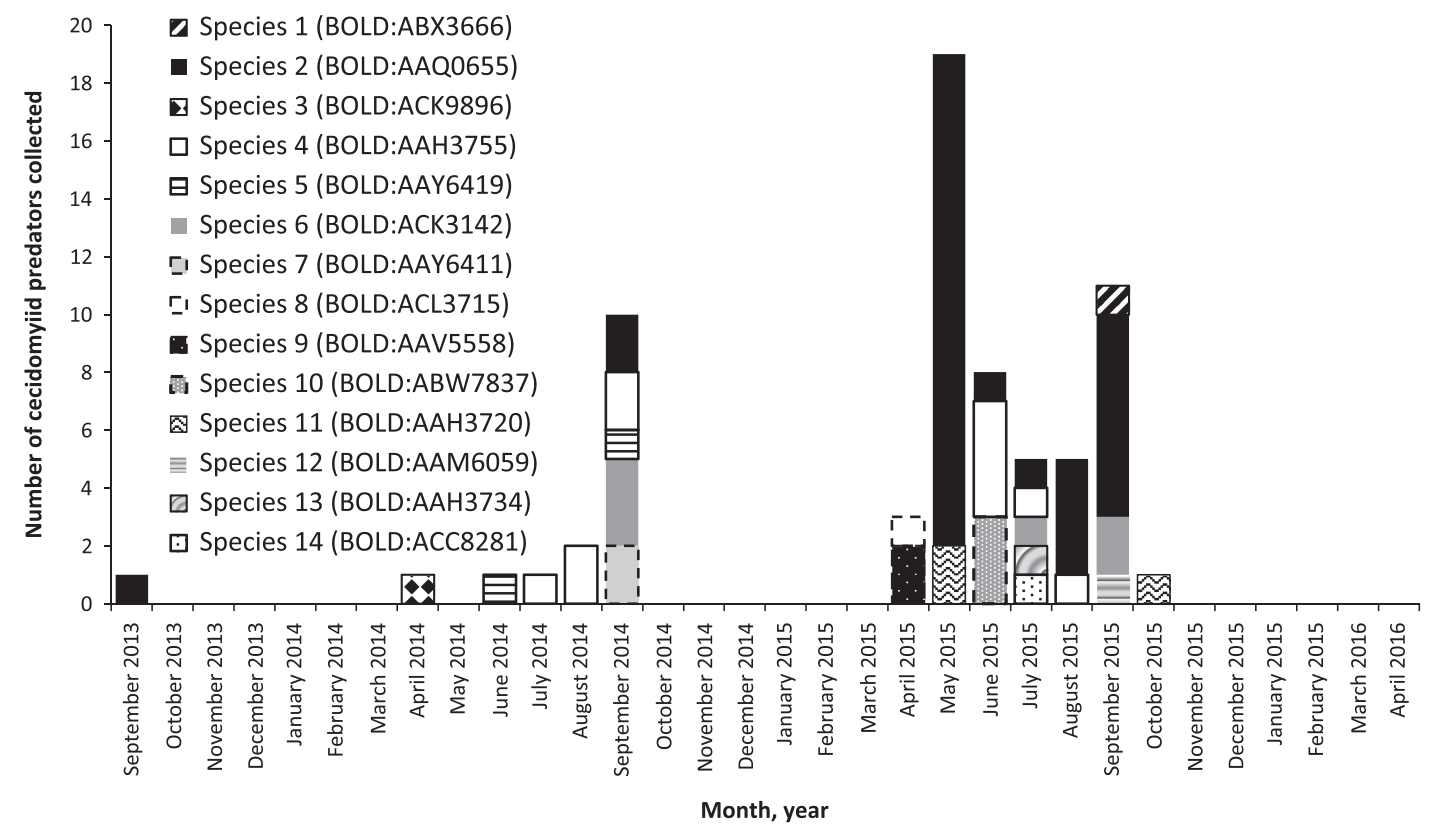

(Gordon 1976). Also collected was one adult Brachiacantha ursina, known to feed on coccids within ant nests and native to Virginia (Vandenberg 2002) (Fig. 3). Several members of this family are predators of other adelgids in other regions. Wallace and Hain (2000) found H. axyridis to be very common on A. tsugae in western North Carolina, United States of America as well, but only from late March to June, whereas the current study found them in large numbers later in the year during October. Green and brown lacewing larvae as well as syrphid larvae were also found in association with $P$. strobi. Chrysopid, hemerobiid, and syrphid species have all been described as predators of $A$. piceae in its native range (Montgomery and Havill 2014). It is important to note, however, that it is not possible to say for certain that these predators were feeding on $P$. strobi.

This study is the first to document the predator complex associated with $P$. strobi in its southern range. The native $P$. strobi specialist $L$. rubidus has an expanded period of activity compared to its northern range, which may allow it greater opportunity for interaction with the invasive
A. tsugae, as well as the closely related biological control agent $L$. nigrinus with which it hybridises. Laricobius rubidus has been observed mating with L. nigrinus in the field (Mausel et al. 2008), and the pairings are known to produce fertile offspring (Havill et al. 2012). The result is a geographic mosaic of hybridisation between the two Laricobius species (Fischer et al. 2015). Despite concern regarding a threat to L. rubidus species integrity and resulting ecological repercussions, hybridisation may have aided in establishment of $L$. nigrinus to the eastern United States of America (Havill et al. 2012). Recent studies indicate that complete hybrid assimilation is unlikely due to the strong respective host preferences of each species (Fischer et al. 2015). Additionally, two species of chamaemyiid currently under consideration as A. tsugae biocontrol agents were found to be present in the environment already in southwestern Virginia and apparently feeding and developing on $P$. strobi. Many cecidomyiid midges were collected, some of which are likely adelgid predators. Although the cecidomyiid community on $P$. strobi remains 
to be fully characterised, this study provides valuable presence data, DNA barcode sequences, and museum vouchers, in advance of their taxonomic identification. It is notable that the $P$. strobi predator complex includes members of the Derodontidae and Chamaeymyiidae, as well as the genus Scymnus (Coccinellidae) all of which specialise on adelgids. This is consistent with other adelgid predator guilds, as is the presence of cecidomyiid midges (Humble 1994; Kohler et al. 2008; Montgomery and Havill 2014). Not only does this work describe the network of species that may use the native adelgid, $P$. strobi, it may also serve to inform future biological control programmes designed to manage invasive adelgid species with which it shares its environment. In addition, increased knowledge of the predatorprey interactions involving $P$. strobi will make it easier to detect and avoid undesirable disturbance to the native ecosystem by introduced predators, such as those intended for $A$. tsugae management (Figs 2-4).

\section{Acknowledgements}

We thank the following individuals for their assistance in sample and data collection: Tom McAvoy, Ryan Mays, Jacqueline Brown, Kat Tanner, Emily Lawrence, Mariah Price, Sara Seeba, Liz Fread, and Rachel Leeth. We appreciate Eric Day's assistance with morphological identification, including the use of his identification laboratory. Thanks also to the United States Department of Agriculture Forest Service and the Town of Pulaski, Virginia for providing research sites for this study. This work was supported by United States Department of Agriculture Forest Service Region 8 grant number 11-DG11083150-010.

\section{References}

Arsenault, A.L., Havill, N.P., Mayfield, A.E., and Wallin, K.F. 2015. Behavioral responses of Laricobius spp. and hybrids (Coleoptera: Derodontidae) to hemlock woolly adelgid and adelgid host tree odors in an olfactometer. Environmental Entomology, 44: 1562-1570.

Brown, W.J. 1944. Some new and poorly known species of Coleoptera. The Canadian Entomologist, 76: $4-10$.
Buffama, P.E. 1962. Observations on the effectiveness and biology of the European predator Laricobius erichsonii Rosen. (Coleoptera: Derodontidae) in Oregon and Washington. The Canadian Entomologist, 94: 461-472.

Burns, R.M. and Honkala, B.H. 1990. Silvics of North America. Volume 1. Conifers. Agriculture Handbook (Washington). United States Department of Agriculture, Washington, District of Columbia, United States of America.

Centre for Agriculture and Bioscience International. 2017. Pineus pini. Invasive species compendium [online]. Available from www.cabi.org/isc/data sheet/41326 [accessed 9 September 2018].

Clark, R.C. and Brown, N.R. 1957. Studies of predators of the balsam woolly aphid, Adelges piceae (Ratz.) (Homoptera: Adelgidae): III. Field identification and some notes on the biology of Neoleucopis pinicola Mall. (Diptera: Chamaemyiidae). The Canadian Entomologist, 89: 404-409.

Clark, R.C. and Brown, N.R. 1960. Studies of predators of the balsam woolly aphid, Adelges peceae (Ratz.) (Homoptera: Adelgidae) VII Laricobius rubidus Lec. (Coleoptera: Derodontidae) a predator Pineus strobi (Htg.) (Homoptera: Adelgidae). The Canadian Entomologist, 92: 237-240.

Darr, M., Salom, S., Brooks, R.K., Foottit, R.G., Miller, G.L., and Havill, N.P. 2018. First report of Pineus strobi (Hartig, 1839) (Hemiptera: Adelgidae) in western North America. Pan-Pacific Entomologist, 94: $1-3$.

Davis, G.A., Havill, N.P., Adelman, Z.N., Caccone, A., Kok, L. T., and Salom, S.M. 2011. DNA barcodes and molecular diagnostics to distinguish an introduced and native Laricobius (Coleoptera: Derodontidae) species in eastern North America. Biological Control, 58: 53-59.

Doane, C.C. 1961. Taxonomy and biology of Pineus strobi (Hartig) and P. coloradensis (Gillette) (Homoptera: Adelgidae). The Canadian Entomologist, 93: 553-560.

Fischer, M.J., Havill, N.P., Brewster, C.C., Davis, G.A., Salom, S.M., and Kok, L.T. 2015. Field assessment of hybridization between Laricobius nigrinus and L. rubidus, predators of Adelgidae. Biological Control, 82: 1-6.

Gagné, R.J. 1989. The plant-feeding gall midges of North America. Cornell University Press, Ithaca, New York, United States of America.

Gordon, R.D. 1976. The Scymnini (Coleoptera: Coccinellidae) of the United States and Canada: key to genera and revision of Scymnus, Nephus, and Diomus. Bulletin of the Buffalo Society of Natural Science, 28: 341-346.

Grubin, S.M., Ross, D.W., and Wallin, K.F. 2011. Prey suitability and phenology of Leucopis spp. (Diptera: Chamaemyiidae) associated with hemlock woolly adelgid (Hemiptera: Adelgidae) in the Pacific Northwest. Environmental Entomology, 40: 14101416. 
Havill, N.P., Davis, G., Mausel, D.L., Klein, J., McDonald, R., Jones, C., et al. 2012. Hybridization between a native and introduced predator of Adelgidae: an unintended result of classical biological control. Biological Control, 63: 359-369.

Havill, N.P. and Foottit, R.G. 2007. Biology and evolution of Adelgidae. Annual Review of Entomology, 52: 325-349.

Havill, N.P., Gaimari, S.D., and Caccone, A. 2018. Cryptic east-west divergence and molecular diagnostics for two species of silver flies (Diptera: Chamaemyiidae: Leucopis) from North America being evaluated for biological control of hemlock woolly adelgid. Biological Control, 121: 23-29.

Havill, N.P., Shiyake, S., Lamb-Galloway, A., Foottit, R.G., Yu, G., Paradis, A., et al. 2016. Ancient and modern colonization of North America by hemlock woolly adelgid, Adelges tsugae (Hemiptera: Adelgidae), an invasive insect from East Asia. Molecular Ecology, 25: 2065-2080.

Hebert, P.D.N., Penton, E.H., Burns, J.M., Janzen, D. H., and Hallwachs, W. 2004. Ten species in one: DNA barcoding reveals cryptic species in the Neotropical skipper butterfly Astraptes fulgerator. Proceedings of the National Academy of Sciences of the United States of America, 101: 14812-14817.

Hebert, P.D., Ratnasingham, S., Zakharov, E.V., Telfer, A.C., Levesque-Beaudin, V., Milton, M.A., et al. 2016. Counting animal species with DNA barcodes: Canadian insects. Philosophical Transactions Royal Society, B, 371(20150333): 1-10.

Humble, L.M. 1994. Recovery of additional exotic predators of balsam woolly adelgid, Adelges piceae (Ratzeburg) (Homoptera: Adelgidae), in British Columbia. The Canadian Entomologist, 126: 1101-1103.

Jenkins, M.A. 2003. Impact of the balsam woolly adelgid (Adelges piceae Ratz.) on an Abies fraseri (Pursh) Poir. dominated stand near the summit of Mount LeConte, Tennessee. Castanea, 68: 109-118.

Kearse, M., Moir, R., Wilson, A., Stones-Havas, S., Cheung, M., Sturrock, S., et al. 2012. Geneious basic: an integrated and extendable desktop software platform for the organization and analysis of sequence data. Bioinformatics, 28: 1647-1649.

Kohler, G.R., Stiefel, V.L., Wallin, K.F., and Ross, D. W. 2008. Predators associated with the hemlock woolly adelgid (Hemiptera: Adelgidae) in the Pacific Northwest. Environmental Entomology, 37: 494-504.

Kohler, G.R., Wallin, W.K., and Ross, D.W. 2016. Seasonal phenology and abundance of Leucopis argenticollis, Leucopis piniperda (Diptera: Chamaemyiidae), Laricobius nigrinus (Coleoptera: Derodontidae) and Adelges tsugae (Hemiptera: Adelgidae) in the Pacific Northwest USA. Bulletin of Entomological Research, 106: 546-550.
Lamb, A.B., Salom, S.M., and Kok, L.T. 2007. Factors influencing aestivation in Laricobius nigrinus (Coleoptera: Derodontidae), a predator of Adelges tsugae (Hemiptera: Adelgidae). The Canadian Entomologist, 139: 576-586.

Lawrence, J.F. and Hlavac, T. 1979. Review of the Derodontidae (Coleoptera: Polyphaga) with new species from North America and Chile. The Coleopterists Bulletin, 33: 369-414.

Mamaev, B.M. and Krivosheina, N.P. 1965. The larvae of gall midges (Diptera: Cecidomyiidae). A.A. Balkema Publishers, Rotterdam, The Netherlands.

Matosevic, D.Z. and Zivkovic, I.P. 2013. Alien phytophagous insect and mite species on woody plants in Croatia. Sumarski List, 137: 191-205.

Mausel, D.L. and Salom, S.M. 2014. Hemlock woolly adelgid. In The use of classical biological control to preserve forests in North America. Edited by R. Van Driesche and R.C Reardon. United States Department of Agriculture Forest Service, Forest Health Technology Enterprise Team, Morgantown, West Virginia, United States of America. Pp. 167-187.

Mausel, D.L., Salom, S.M., Kok, LT., and Davis, G.A. 2010. Establishment of the hemlock woolly adelgid predator, Laricobius nigrinus (Coleoptera: Derodontidae), in the eastern United States. Environmental Entomology, 39: 440-448.

Mausel, D.L., Salom, S.M., Kok, L.T., and Fidgen, J.G. 2008. Propagation, synchrony, and impact of introduced and native Laricobius spp. (Coleoptera: Derodontidae) on hemlock woolly adelgid in Virginia. Environmental Entomology, 37: 1498-1507.

McClure, M.S. 1982. Distribution and damage of two Pineus species (Homoptera: Adelgidae) on red pine in New England. Annals of the Entomological Society of America, 75: 150-157.

McClure, M.S. 1984. Pineus boerneri Annand (Homoptera: Adelgidae): a new or another record from the People's Republic of China? Proceedings of the Entomological Society of Washington, 86: 460-461.

McClure, M.S. 1989. Evidence of a polymorphic lifecycle in the hemlock woolly adelgid, Adeges tsugae (Homoptera, Adelgidae). Annals of the Entomological Society of America, 82: 50-54.

McManamay, R.H., Resler, L.M., Campbell, J.B., and McManamay, R.A. 2011. Assessing the impacts of balsam woolly adelgid (Adelges piceae Ratz.) and anthropogenic disturbance on the stand structure and mortality of Fraser fir [Abies fraseri (Pursh) Poir.] in the Black Mountains, North Carolina. Castanea, 76: 1-19.

Montgomery, M.E. and Havill, N.P. 2014. Balsam woolly adelgid. In The use of classical biological control to preserve forests in North America. Edited by R. Van Driesche and R.C. Reardon. United States Department of Agriculture Forest Service, Forest Health Technology Enterprise Team, Morgantown, West Virginia, United States of America. Pp. 9-19. 
Montgomery, M.E. and Lyon, S.M. 1995a. Natural enemies of adelgids in North America: their prospect for biological control of Adelges tsuga (Homoptera: Adelgidae). In Proceedings of the first hemlock woolly adelgid review. Edited by S.M. Salom, T.C. Tigner, and R.C. Reardon. United States Department of Agriculture Forest Service, Forest Health Technology Enterprise Team, Morgantown, West Virginia, United States of America. Pp. 89-102.

Montgomery, M.E. and Lyon, S.M. 1995b. Scymnus (Pullus) suturalis Thunberg (Coleoptera: Coccinellidae): new locality records and a report on feeding on hemlock woolly adelgid, Adelges tsugae Annand (Homoptera: Adelgidae). The Coleopterists Bulletin, 49: 118 .

Montgomery, M.E., Shiyake, S., Havill, N.P., and Leschen, R.A.B. 2011. A new species of Laricobius (Coleoptera: Derodontidae) from Japan with phylogeny and a key for native and introduced congeners in North America. Annals of the Entomological Society of America, 104: 389-401.

Motley, K., Havill, N.P., Arsenault-Benoit, A.L., Mayfield, A.E., Ott, D.S., Ross, D., et al. 2017. Feeding by Leucopis argenticollis and Leucopis piniperda (Diptera: Chamaemyiidae) from the western USA on Adelges tsugae (Hemiptera: Adelgidae) in the eastern USA. Bulletin of Entomological Research, 107: 699-704.

Raske, A.G. and Hodson, A.C. 1964. The development of Pineus strobi (Hartig) (Adelginae, Phylloxeridae) on white pine and black spruce. The Canadian Entomologist, 96: 599-616.

Ratnasingham, S. and Hebert, P.D.N. 2007. BOLD: The barcode of life data system. (www.barcodinglife.org). Molecular Ecology Notes, 7: 355-364.

Ross, D.W., Grubin, S.M., Kohler, G.R., and Wallin, K. F. 2010. Evaluation of Leucopis species (Diptera: Chamaemyiidae) from the PNW as potential biological controls for the hemlock woolly adelgid. In Fifth symposium on hemlock woolly adelgid in the eastern United States. Edited by B. Onken and R.C. Reardon. United States Department of Agriculture Forest Service, Forest Health Technology Enterprise Team, Morgantown, West Virginia, United States of America. Pp. 32.

Roy, H.E., Brown, P.M.J., Adriaens, T., Berkvens, N., Borges, I., Clusella-Trullas, S., et al. 2016. The harlequin ladybird, Harmonia axyridis: global perspectives on invasion history and ecology. Biological Invasions, 18: 997-1044.
Sluss, T.P. and Foote, B.A. 1973. Biology and immagure stages of Leucopis pinicola and Chamaemyia polystigma (Diptera: Chamaemyiidae). The Canadian Entomologist, 105: 1443-1452.

Story, H.M., Vieira, L.C., Salom, S.M., and Kok, L.T. 2012. Assessing performance and competition among three Laricobius (Coleoptera: Derodontidae) species, predators of hemlock woolly adelgid, Adelges tsugae (Hemiptera: Adelgidae). Environmental Entomology, 41: 896-904.

Vandenberg, N.J. 2002. Coccinellidae Latreille 1807. In American beetles, volume 2: Polyphaga: Scarabaeoidea through Curculionoidea. Edited by R.H. Arnett, M.C. Thomas, P.E. Skelley, and J.H. Frank. CRC Press, Boca Raton, Florida, United States of America. Pp. 371-389.

Vieira, L.C., Lamb, A.B., Shiyake, S., Salom, S.M., and Kok, L.T. 2013. Seasonal abundance and synchrony between Laricobius osakensis (Coleoptera: Derodontidae) and its prey, Adelges tsugae (Hemiptera: Adelgidae), in Japan. Annals of the Entomological Society of America, 106: 249-257.

Wallace, M.S. and Hain, F.P. 2000. Field surveys and evaluation of native and established predators of the hemlock woolly adelgid (Homoptera: Adelgidae) in the southeastern United States. Environmental Entomology, 29: 638-644.

Wantuch, H.W., Kuhar, T.P., and Salom, S.M. 2017. Phenology of the pine bark adelgid, Pineus strobi (Hemiptera: Adelgidae), in white pine forests of southwestern Virginia. Environmental Entomology, 46: 1195-1201.

Wilson, F. 1938. Notes on the insect enemies of Chermes with particular reference to Pineus pini, Koch, and Pineus strobi, Hartig. Bulletin of Entomological Research, 29: 373-389.

Zilahi-Balogh, G.M.G., Broeckling, C.D., Kok, L.T., and Salom, S.M. 2005. Comparison between a native and exotic adelgid as hosts for Laricobius rubidus (Coleoptera: Derodontidae). Biocontrol Science and Technology, 15: 165-171.

Zilahi-Balogh, G.M.G., Humble, L.M., Lamb, A.B., Salom, S.M., and Kok, L.T. 2003. Seasonal abundance and synchrony between Laricobius nigrinus (Coleoptera: Derodontidae) and its prey, the hemlock woolly adelgid (Hemiptera: Adelgidae). The Canadian Entomologist, 135: 103-115.

Zilahi-Balogh, G.M.G., Kok, L.T., and Salom, S.M. 2002. Host specificity of Laricobius nigrinus Fender (Coleoptera: Derodontidae), a potential biological control agent of the hemlock woolly adelgid, Adelges tsugae Annand (Homoptera: Adelgidae). Biological Control, 24: 192-198. 